\title{
WHITE FEELINGS AND BLACK KNOWLEDGE: TACKLING RACISM AND EPISTEMIC VIOLENCE IN GERMAN HIGHER EDUCATION
}

\author{
F. ANGELO CAMUFINGO \\ University of Potsdam
}

\section{ABSTRACT}

This article provides insight on the production and passing on of "knowledge" and the idea of a possible objectivity particularly conveyed in Western universities. It deals with how forming a university group tackles the continuations of such thoughts. The article starts by reflecting on statements and practices of a university seminar of which I was a participant. The course examined hip hop culture through language, investigating lyrics from a cultural linguistics perspective. It served as an example of epistemic violence and racist continuations and reproductions at universities that try to promote their anti "whatever -isms" attitudes. Next, I provide theoretical background on the fantasy of academic objectivity and its resultant racism, and explain the formation of a Black university group. I will explore the group's experiences and struggles to critique Western universities and knowledge transfer while actively being part of them. The group's work is an exemplary way of how to question existing structures and of resisting imposed and racist ideas of knowledge and truths.
KEYWORDS

epistemic violence, Western universities, German higher education, Black university group, racism, whiteness

\section{TACRLING RACISM AND EPISTEMIC VIOLENCE IN GERMAN HIGHER EDUCATION} Racism is a topic that is often hushed up in Germany. A lot of that has to do with the country's holocaust history and its subsequent rejection of anything that includes the word "race" as it seems to serve as a reminder of a past that the country wants to file as "lesson learned, we're tolerant now." There even seems to be a partial belief that use of the word "race" will lead to racism. However, Germany does have an issue with racism, especially targeted toward Black people, that has to be addressed. Prior to university, we did not learn a lot about German colonialism, but focused instead on shaming Great Britain. No one told us about the realities of Black people and the "nostalgic" glorification of colonial Africa during the times of National Socialism, or all the racist incidents in the German Democratic Republic (former East Germany), the Federal Republic 
of Germany (former West Germany), and in reunified Germany that the gastarbeiter ${ }^{1}$ faced (Selter, 2007). Yet, the results are all too noticeable. It is not for nothing that the United Nations called out the German police for having a racism issue and accused the country of structural racism in 2016 and 2017 (UN, 2017). Racism begins in kindergarten, if not at birth, and accompanies Black people through their lives.

The current point in my life where I experience racism the most? University:

At first, I want to clarify that even when using 'harsh' language, no one in this room is racist, but sometimes it is impossible not to reproduce certain things. However, we are academics and thus have an objective perspective on these things. So, when I say [N-word], nobody in this room has to feel attacked. This is science. (Anonymous, 19 Oct 2016)

This is just one of many examples and was said by one of my white ${ }^{2}$ professors, while addressing forty nodding white heads. She seemed satisfied, thinking that although she had just used the N-word four times, the students "got her" and she would have successfully desensitized me to what was to come and how I should feel or not feel about it.

However, I raised my hand and expressed my discomfort about the reproduction of racist terminology, and also about the absurd idea that the works of white scholars were objective. I caused a storm of indignation, sighs, "evil eyes," and fellow students asking me, "Are you being serious right now?"

The statement I quoted from the professor is only one of many that were made during my studies on the subject of postcolonialism and in pseudo anti-racist courses, with a seemingly non-white focus. It was an exemplary centralization of privileged people and their feelings that their "clean sheet" and "good intentions" were being attacked. The course was ostensibly about looking at hip hop culture through its language, investigating lyrics from a cultural linguistics perspective. After providing theoretical insight into the subject matter and methods of analysis, the main focus was on examining various conceptualizations, or social perceptions, such as how being Black is conceptualized in hip hop.

I endured thirteen weeks of constant disregard, questioning, and pretended difficulty about avoiding the use of certain terminology in their analysis of lyrics, as for example the

1. People with temporary permissions to work in Germany.

2. The reason I capitalize "Black" is explanatory to why I do not capitalize "white". It does not have identitarian value to white people in the sense of a self-determinant nor has it to be centralized. 
n-word. Students asked me what they should say instead, and explained how challenging it was to learn "new" words and unlearn others. When it was my turn to I endured thirteen weeks of constant disregard, questioning, and pretended difficulty about avoiding the use of certain terminology in their analysis of lyrics, as for example the $\mathrm{N}$-word.

give a presentation, I factually explained my standpoint and gave examples, citing Black scholars. I spoke about conceptualizations of being Black, Black realities, and the N-word. Indeed, some white students understood, some approached me afterwards and thanked me for my input, but from others I heard statements such as "I didn't even know these people" (referring to the Black academics I had cited) and "the other Black guy [attending the course] said he didn't care and all his white friends call him [N-word]".

\section{ORIGINS OF RNOWLEDGE} It seemed as if my knowledge did not hold power. Could I, a Black man, born in Germany, even consider what I knew as knowledge? Why did "their" knowledge hold power over mine, and what could I do about it?

Episteme is a key term used by Foucault when defining "truths." It means something that all human beings expect to be known, true, or established. The question, which Foucault also seemed to aim for in works such as Discipline and Punish, is how does something become truth? How does it become knowledge? Foucault posited that what we hold as truths have been based on underlying assumptions; epistemes define our lives as they are what we see as "given" or "obvious to know," as fundamental, even "normal." However, by that very definition they are also excluding, because not every human being has the same idea about what is "normal" or primal and what is not. Ramon Grosfoguel wrote an article called "The Structure of Knowledge in Westernized Universities" in which he explains how epistemic racism and sexism-racism and sexism based on certain ideas of truths - are responsible for today's structure of knowledge, for the perpetuation of things people accept or used to accept to be truths and reality:

In Westernized universities, the knowledge produced by other [social systems, "truths," realities], and world views arising from other world-regions with diverse time / space dimensions and characterized by different [developments and ideas] of knowledge are considered 'inferior' in relation to the 'superior' knowledge produced by the few Western men [...]. (Grosfoguel, 2013, p. 74) 
He continues to explain how epistemicides, or extinctions of knowledge that were mostly genocides, created the idea of a god-like "I," of white superiority, how some white Western men achieved "such an epistemic privilege to the point that their knowledge today is considered superior over the knowledge of the rest of the world" (Grosfoguel, 2013, p. 30).

Racism and power structures were strengthened through European practices that included capturing land, killing people, colonizing, enslaving, and attempting to "scientifically" demonstrate the inferiority of people by positing racial theories and suppressing and wiping out indigenous knowledges. In the long run, that lead to teenagers like me, who asked themselves why there seemed to be no paternal or maternal ancestors who had ever written something "worthy enough" to be taught in school. This whole process is still ongoing. The effect, or racist product, of this wiping out and suppression prevented and still discourages non-white people from speaking out, thinking freely, and producing, putting down, or gaining knowledge. At the same time, it prevents the knowledge that they actively produce from being considered as such. It is a process that continues even when the belief in a biological concept of race becomes untenable.

The effect, or racist product, of this wiping out and suppression prevented and still discourages non-white people from speaking out, thinking freely, and producing, putting down, or gaining knowledge.

Even though universities claim to be anti "whatever isms" and to include racialized bodies to some extent, they are still about whiteness. Lecturers try to include people such as Franz Fanon or maybe even Anta Diop. However, besides the fact that, even then, it is very much about cisgendered men and still excludes many worldviews, scholars who are seen as "non-Western" or not-white are still treated as rarities or even as curiosities. They are presented to students as something "other," with otherness being just another aspect deriving from the idea of white superiority, constituting the reason for its existence. Through power, a norm was created by othering realities, knowledge, and groups of people and thus determining political minority and majority identities. Of course, I can speak only from the perspective of what I and my friends have experienced in the course of our studies, and there might be a few more preferable examples, but they simply prove the rule: universities are reproducing epistemic violence, violence toward knowledge that manifests in institutional racism and a myth of objectivity, and, as Grosfoguel (2013) put it, "an 'l' that assumes itself to be producing knowledge from no-where" (p. 76). They are entrenching Western notions of the composition of power and 
continue to not only marginalize non-Western knowledge but also to rule out ways for racialized people to contribute to what a lot of universities try to promote.

This does not manifest itself exclusively in curriculums or lesson content but also in what societies call "common knowledge," "folk wisdom," and jokes, and in media and other areas of everyday life. The perception of resistance to such racist "knowledge," to imposed structures and supposed facts, as emotional and non-objective, is also exemplary. Even a substantive refutation, such as why racist terminology should not be accepted just because it is used in an academic context, is made clear by the fact that the decision to do so basically comes from a white perspective. It is a white concept to argue that just because someone experiences what they are talking about, they could not objectively argue for it or against it. This belief is traceable to Plato in Greek philosophy and the assumption of ideas as being more real than experienced reality.

My exemplar ends with a final discussion initiated by the professor during the last week of that semester, attempting to prove all my points wrong and breaking apart my ongoing struggle to include non-Western knowledge in my presentation and in-class contributions. By showing a short clip on racism, in which a plethora of racist terminology was quoted, she reinforced the idea of not being able to avoid it, telling me how my feelings were simply different from the feelings of other Black people, leading white fellow students to tell me I should be more about "actual" science and put my feelings aside. They told me they had been hurt when I had implied, twelve weeks before, that they were racist. What was not mentioned was that the film was from the early 90 s and was scripted and directed by a white man.

This proved to me that my thoughts would never be seen as knowledge, but as feelings, and that academic objectivity was, despite being a fantasy, a privilege of white people.

However, subjectivity is important. Why do we act as if people who experience different things and then record them are creating knowledge that is less worthy than knowledge that is produced with the delusional attempt to disconnect learning from the subject? Knowledge starts with experiencing

Knowledge starts with experiencing something and in my opinion the subject in that experience is the essence of truths and realities. something and in my opinion the subject in that experience is the essence of truths and realities. In regard to racism, for example, who would be a better source of knowledge than someone who experienced it? 
FORMING A UNIVERSITY GROUP Now what could I do to make Western universities aware of these problems? I decided to start by trying to have an impact on my university.

First of all, higher education in general needs to be critiqued in various ways. Part of the problem is its exclusivity and contribution to social inequality on the basis of educational access, which is in turn determined by social origin that is shaped by aspects of identity such as race. However, the way in which I approached the problem was more based on the apprenticing purpose of universities. Part of the underlying problem is that people who go to universities are the people who teach children, who are responsible for school systems, curricula, reading lists and general educational content, people who write articles and books, and who go back to universities to teach people who will then again teach others. Thus, the problem is the ongoing reproduction that influences so many fields in life. It is a reproduction that dismisses and negates people like meBlack people-and, of course, other racialized and marginalized people, along with our opinions, experiences, feelings and, most important, our knowledge. In response to this situation, seven students from the University of Potsdam who identify as Black formed a university group. That might not sound innovative, but the idea was new to us, to me. It was new to realize that I could do something and that there are Black people who feel what I feel.

We decided to change something, and we decided to do it together, in a German context that I had often believed to be unchangeable.

It was new to think about the idea of not simply accepting "that's just university, so let's get over it." We decided to change something, and we decided to do it together, in a German context that I had often believed to be unchangeable.

\section{T H E BEG I N N I NG S} Called the Schwarze Diaspora Hochschulgruppe Potsdam (SDHG) (Black Diaspora University Group Potsdam), we officially formed in February 2017. However, our story began in November 2016, when two of my friends and I conceptualized the idea of what would later become the university group. After getting to know each other and empowering each other, sharing ideas, sentiments and thoughts, we finished our concept and presented it to the other students. We immediately registered seven members and currently count fourteen and rising (we also welcome Black people who do not study). One of the most important steps for me was this official registration as a university group. We became visible and an official and inherent part of the university structure. The founding of this group alone 
has had a great deal of impact in terms of acknowledgement, but also regarding initial hostilities toward us, accusing us of promoting segregation. As we launched our online presence by posting a short portfolio and an article on intersectionality, another university group took aim at us. They claimed to be all about peace, but they started to attack us for pointing out the need for the empowerment of Black people, the use of the term "diaspora," and highlighting the importance of intersectionality and safer spaces. They trivialized racism and the necessity of our group by stating how using the word "diaspora" was an appropriation of the Jewish community, how speaking about safer spaces was appropriating feminist spaces, and how believing in intersectionality would be an attempt to downplay other forms of discrimination. Their paragraphs read like attempted diagnoses, ending by stating we were simply dissatisfied children with an issue adapting to society and lacking "real" problems.

In the beginning, we were also criticized for becoming part of an institution and thus also subject to the conditions imposed by it. Indeed, our approach follows exactly that direction. By registering, we have access to facilities we would not otherwise have, as well as being in charge and having a voice in certain areas. We chose to try and change something from the "inside" out.

In addition to goals such as the empowerment of Black students, above all we want to exert lasting influence against racism at the university. That includes the university's engagement with racist terminology, a wider and more diverse curriculum, giving permanent positions to teachers of political minorities, diversity trainings for administrative staff and teachers, and an ongoing acknowledgement of the living realities of Black students and other discriminations by the university itself, as well as by other students.

OUR WOR R Currently, we are still working on ideas to optimally and effectively intervene into the activities of professors and other student organizations and groups, what events to plan at our university, and how to create a continuation of actions in order to maximize our impact.

So far, we have been involved in giving lectures on racism at our university, brainstorming strategies for starting a group such as ours, and developing it in various directions. A special highlight was the "Colloq of Action" in Berlin, an event to learn from and about each other and the different struggles against colonial conditions in academia. A colloq, or colloquium, is a specialist or academic exchange in an open format. It was meant to bring current dynamics and structures at German universities 
together with a critical examination of German and European colonial history. After introducing our group and its work, we took part in a strategy session on potentials and pitfalls regarding an involvement in university politics and antiracist work on the campus. Separated into two groups, we developed visions, like the empowerment of Black students, and accompanying missions, like applying for funds to organize an empowerment workshops. Afterwards, we talked about potentials, such as creating a continuity in offering empowerment workshops for various people who are discriminated against, and possible pitfalls, like the university's interference in how the workshops take place as they finance them. In the end, we had to choose the subjects that were most important to us. The colloq reinforced my wish to collectively establish our group, but it also reemphasized the challenges we are facing.

\section{CHALLENGES AND TIPS}

I often get the feeling that many contemporary student activist groups are ending their work too soon because they are told that their problems are not "big enough," that people still enjoy too many privileges, and that sometimes it seems easier to do nothing. That is exactly where I think a big task lies, because not to be blinded by these perceptions and to continue to resist in any form that works for you is a big part of what I think of as Black knowledge, and what debilitates white feelings. Comforting white people while addressing racism and power structures is

That is exactly where I think a big task lies, because not to be blinded by these perceptions and to continue to resist in any form that works for you is a big part of what I think of as Black knowledge, and what debilitates white feelings.

relieving them of their responsibilities to deal with their past, their privilege, and how those aspects are connected to inequality. White feelings in this context reflect the fear of being deposed from their privileges and facing different realities and knowledge that might seem contrary to what we have been taught in Westernized education.

For me, the group means to show not only Black people, but also other people who are discriminated against, that you do not have to accept the existing structures and that you should not look away just because you think your studies will be over soon. For me, it means the opportunity to change things for people coming after me. For me, it means to be visible and to feel existent for the first time, in a university context and a context of knowledge and education that negates racialized people. 
A C K N OW L E D G M E N T S

I would like to thank every member of the university group for inspiring me with their individuality and strength and for making me look forward to University again.

\section{R E F E R E N C E S}

Foucault, M. (1977). Discipline and punish: The birth of the prison (A. Sheridan, Trans.). London, UK: Penguin Books.

Foucault, M. (2002). The order of things: An archaeology of the human sciences. London, UK: Routledge.

Grosfoguel, R. (2013). The structure of knowledge in Westernized Universities: Epistemic racism/ sexism and the four genocides/epistemicides of the long 16th century. Human Architecture: Journal of the Sociology of Self-Knowledge 11(1), 73-90. Retrieved from https:// scholarworks.umb.edu/humanarchitecture/vol11/iss $1 / 8$ Plato. (2008). Great dialogues of Plato (W. H. D. Rouse, Trans.). New York, NY: Signet.

Selter, K. (2007). Rassismus in der deutschen Gesellschaft seit der Wiedervereinigung. [Racism in German society since reunification]. München, Germany: GRIN Verlag.

United Nations. (2017). United Nations Human Rights Office of the High Commissioner: Statement to the media by the United Nations' Working Group of Experts on People of African Descent, on the conclusion of its official visit to Germany, 20-27 February 2017. Retrieved from https:// www.ohchr.org/EN/NewsEvents/Pages/DisplayNews. aspx?News $\mid \mathrm{D}=21233 \&$ Lang $\mid \mathrm{D}=\mathrm{E}$ 